\title{
Control and Management of the Pine Weevil Hylobius abietis $L$.
}

\author{
Amelia TUDORAN*, Ion OLTEAN, Mircea VARGA \\ Department of Plants Protection, University of Agricultural Sciences and Veterinary Medicine of Cluj- \\ Napoca, Romania \\ *corresponding author: amelia.tudoran@usamvcluj.ro
}

BulletinUASVM Horticulture 76(1) / 2019

Print ISSN 1843-5254, Electronic ISSN 1843-5394

DOI:10.15835/buasvmcn-hort: 2018.0049

\begin{abstract}
The pine weevil, Hylobius abietis L., is a pest of economic importance causing massive damage to conifer seedlings planted on reforestation sites. The lack of effective methods to prevent establishment of $\mathrm{H}$. abietis in newly-harvested sites makes it a threat to European forests. The biology and ecology of the pine weevil have been intensely studied through the years. However, in light of current and future climate change much of the knowledge gathered thus far may need to be re-evaluated under these new conditions. Changes in temperature and other climatic variables may strongly change, for example, the development of the weevil and its distribution. Such changes may result in higher population numbers and increase the feeding pressure on newly planted seedlings, thus making it a novel pest in certain areas or increasing its pest status in others. There is a need to synthesize our current understanding on the biology, behavior and methods of damage control by the pine weevil H. abietis, in order to identify knowledge gaps and propose new management practices. In this review, we present such an overview and provide several examples on how this knowledge could be expanded or used to meet future challenges.
\end{abstract}

Keywords: Control, Hylobius abietis, monitoring, prevention

\section{Introduction}

Hylobius abietis is considered to be the main pest of forest plantations across Europe, at least in 15 countries and on approximately 3.4 mil. hectares of forest (McNamera et al., 2018), and also in Asia (Leather et al., 1999). The large pine weevil became a pest starting in the $19^{\text {th }}$ century (Leather et al., 1999) and it remains a threat, especially given current regulations against the application of pesticides in forest sites, synthetic pyrethroids such as deltamethrin and cypermethrin (Leather et al., 1999), although deltamethrin has been shown to have low persistence (Viiri et al., 2007). However, in Romania it became a pest much later since clear cutting of conifer forests started later than the rest of Europe. Regeneration has been done either naturally or through seed planting during the first few decades of the $20^{\text {th }}$ century
(Olenici, and Olenici, 1994). Thus, the first reports of attacks by Hylobius started during the $4^{\text {th }}$ decade of the current century (Leather et al., 1999), with the first written studies on the species dating from around the same time (Olenici, and Olenici, 1994). Currently, there are no official estimates on the amount of bark-feeding damage produced by H. abietis in Romania, where the main problems occur in nurseries.

In light of the challenges we face due to global warming, it is imperative that we examine various current and future alternatives to control this species, as well as re-evaluate the knowledge gathered so far. The potential influence of climate change on the pine weevil is relatively unknown, therefore there is a need to increase and update the current information. Some studies have shown that changes in the pine weevil's life cycle can 
occur (Inward et. al., 2012), thus, we can expect the species distribution and population to differ from the current one. Considering that host plant distribution and adaptation are also likely to change with global warming (Dyderski et al., 2017) their susceptibility to attack by insect pests could increase or decrease under future scenarios. . In this article, we focus on identifying the knowledge gaps and the information gathered so far in order to pose unanswered questions and new possibilities of protecting the seedlings against the pine weevil. We present an overview of the life cycle of the pine weevil, as well as damage and control measures.

\section{Life cycle}

Hylobius abietis develops in roots or stumps of dead conifer trees, laying its eggs in the bark of conifer stumps. Although predominantly semivoltine, the influence of temperature on weevil mass is likely to have a positive effect on fecundity and overwintering survival (Inward et. al., 2012). Depending on the microclimate and the quality of the stumps, the life cycle can be between 12-36 months, but it can reach 5 years in areas with cold climate (Dillon and Griffin, 2008). Considering they are poikilothermic organisms, all insects have their development conditioned by the temperature of the environment. In Hylobius abietis' case, this influence is manifesting itself much stronger than in other species due to the its long oviposition period; and also, that the larva can develop at various soil depth levels. In Europe, the amount of time needed from the moment of emergence from the egg up to its first reproduction is around 2 years (CABI, 2015). Furthermore, the development highly depends on the quality of the host, temperature and oviposition factors. Populations vary in size, depending on the age and condition of the host plant (Davis et al., 2008).

Adults generally emerge from hibernation during the spring, when the temperatures reach $8-9{ }^{\circ} \mathrm{C}$ (Nordenhem, 1989). The activity of the adult is very dependent of temperature, light and humidity, preferring a temperature of approximately 20 to 25 degrees for feeding and oviposition (Christiansen and Bakke, 1968). Flight takes place at temperatures of over $18-19{ }^{\circ} \mathrm{C}$, with a wind speed of 3-4 m/s-1 (Day et al., 2004). Adults disperse looking for new hosts where they will feed up to maturity in the crowns of adult trees (Day et al., 2004). According to Fedderwitz et al. (2014) pine weevils allocate $6 \%$ of their time to feeding, making 4-5 meals a day, eating about $13 \mathrm{~mm}^{2}$ (debarked stem area) per meal. Feeding depends on the species of conifer, the depth of bark and temperature (Day et al., 2004). Adults feed on the stem and roots of seedlings, and can often be found in the crowns of adult trees (Fedderwitz et al., 2018).

Copulation takes period between May and August, which is a relatively long period (Lekander et al., 1985). Tilles et al. (1986) showed that $H$. abietis individuals do not use pheromones to recognize one another over high distances, but merely over a few centimeters. However, sex-specific recognition occurs at very short distances (Tilles et al. 1987). After mating takes place, the females lay their eggs in the fresh stumps of conifers. Feeding as well as oviposition are affected by climate conditions (Bylund et al., 2004). Oviposition takes place from May up until September, with a peak in the middle of May up to the beginning of June (Leather et al., 1999). Larvae emerge and start feeding subcortically on the bark. Host quality for feeding larvae has a large impact over the early stages of reproduction of the pine weevil (Thorpe et al., 2008). In general, for the larva in their $3^{\text {rd }}$ and $4^{\text {th }}$ instar as well as for the adults, overwintering takes place in the pupal chambers (Nordenhem, 1989). As the temperature drops (generally under $8^{\circ} \mathrm{C}$ ), adults migrate towards the soil for hibernation (Leather et al., 1999), usually being found in the soil litter of mature forests. The insect behavior is dependent on environmental factors and the insect itself physiologically speaking (Leather et al., 1999). Nordenhem and Eidmann (1991) suggest that $H$. abietis has a different reaction to various attractants depending on its development stage. The spatial orientation of the adult is dependent on light and humidity, and the response to these factors varies according to the insects' developmental stage (Leather et al., 1999). The weevils respond also to acoustic signals and volatiles of host plants (Leather et al., 1999).

The potential effects of climate change on the pine weevil's life cycle have been little studied, although longer summers and increased temperatures are likely to have an effect on the weevils (Tan et al., 2010). Thus, potentially leading to future increases in pine weevil population size 
and the damage to planted seedlings. To identify morphological changes in the pine weevils, related to climate change, we could examine the sexual organs of the adults. Identifying changes related to the timing of sexual maturity could give an indication of how mating and oviposition might shift due to climate change. Thus, providing a window of opportunity to interfere with its cycle and use this as a control method. Such studies have been done on Listronotus maculicollis (Coleoptera: Curculionidae) (Wu et al., 2017), and it has been shown that low temperature prevented reproductive development. If we examine the effect of different climatic variables on the reproductive development of the pine weevils, we could potentially use this information to enhance pest control in future scenarios.

\section{Damage}

Hylobius abietis causes damage especially to hosts freshly planted in clear cuts or next to 2-3 year old forests or trees with damaged branches (Leather et al., 1999; CABI 2015). The damaged tissue emits chemicals that attract the adults recently emerged from infested sites to new hosts. Transplanted seedlings are vulnerable because the population densities of weevils on a site are often large relative to the availability of conifer stem material (Leather et al., 1999). Therefore, high levels of damage to seedlings and subsequent mortality are common in the plantations.

It has been shown that the damage can be influenced by the type of soil used when planting the seedlings, the damage being reduced when seedlings were planted in mineral soil (Kindvall et al., 2000). The pine weevil avoids feeding on seedlings planted in mineral soil, however if vegetation is present, the pine weevils are encouraged to stay and feed on the seedlings (Petersson et al., 2006). In a similar manner, it is recommended to retain green trees in sites where burning is applied as a silvicultural treatment, in order to reduce the damage caused by the pine weevils (Pitkänen et al., 2005). Further studies have shown that retention of trees could provide an alternative food source, therefore reducing the damage towards seedlings (Pikänen et al., 2008).

In Romania, although we use both shelterwood system and clear cutting, our silvicultural systems do allow for natural regeneration to take place. In the sites where $H$. abietis occurs, it is recommended to take control measures to prevent major seedling mortality (Leather et al., 1999; Albrecht et al., 2008). Without control measures, young plantations, about 2 years old, suffer between 30 and 100\% seedling mortality in Europe (Albrecht et al., 2008; CABI 2015). The damage is not consistent between plantations, it can differ from one plantation to another. This is because each site has a different microclimate and different substrate. To improve pest control, variables at different sites could be examined, and levels of pine weevil damage assessed in relation to manipulation of these variables. Results from different sites could be compared, and a general pest control approach could be recommended.

The influence of silvicultural techniques over the populations of $H$. abietis is complex and poorly understood (Leather et al., 1999). Freshly cut parcels, as well as those resulting from forest fires, are invaded by a large number of beetles from the first vegetation period after the appearance of these surfaces. There are numerous observations confirming that the most powerful infestations occur in these areas (Olenici and Olenici, 1994). Most of the population attacking a fresh plantation comes by migration from one site to another, very few result from the overwintering grounds of the remaining stumps. The pine weevils that fly quickly occupy the entire surface uniformly; while the weevils moving on the ground focus initially in the edges of the site slowly advancing towards the center, with a speed of up to $30 \mathrm{~m} /$ day without a preferred direction (Olenici, and Olenici, 1994).

\section{Control}

Measures to reduce and control levels of damage by $H$. abietis are necessary in areas where silvicultural practices include clear-cutting and replanting to regenerate the forest (Wallertz et al., 2014). In Romania, due to common occurrence of mixed forests, the percentage of economical loss has not been as great as in other European countries that focus on monoculture stands. In the past, seedling protection against the pine weevil involved pre-planting and/or post-planting application of insecticides, e.g. pyrethroids. Preplanting pesticide application was done to the bare roots of seedlings, while post-planting refers to spraying the seedlings with lower concentration of pesticide (Leather et al., 1999). It has been shown that pine weevils tend to avoid untreated seedlings 
over pesticide treated seedlings (insecticides: imidacloprid and neonicotinoid); moreover, the death of the pine weevils can occur up to 3 weeks from treatment (Rose et al., 2005). Thus, a variety of different strategies have been used to prevent and reduce damage by the pine weevil.

Control methods include, among others, monitoring of $\mathrm{H}$. abietis populations and masstrapping of the insects. Estimating the number of adult weevils in forest plantations is done using traps, manufactured from branches, freshly cut pieces of fresh bark or traps with various attractants. The traps have to be installed in the conifer plantations in the beginning of April up until September, and they have to be checked every week in order to monitor the number of adults caught. Olenici and Olenici (1994) have found, in the course of two years, a series of areas with moderate attack, strong attack and even very strong attack despite of the different measures of protection applied on the sites, including toxic bark. The failures are due to various causes: not enough traps, late placement of traps or late replacement, and possibly the pesticide used (e.g., pesticides such Detox or Heclotox may be too old to be effective; Decis has very short duration time, especially in low concentration (Oleniciand Olenici, 1994). Although the insecticides Decis and Karate Zeon seem to be effective against the pine weevil, they can have long-term effects on the seedling growth and development (Luoranen and Viiri, 2005). Other trapping methods included using baited pitfall traps of various designs containing bait fluid, a mix of turpentine and ethanol (Voolma, 1994). Later on, Olenici and Olenici (2006) have tested NeemAzal-T/S successfully, although a concentration of $20 \%$ or more proves effective.

Albeit the mechanism underlying host recognition by the pine weevil is not fully understood, the principle of luring the weevils with the volatiles from fresh bark or branches (especially pine and spruce) has been used since the end of the last century (Leather et al., 1999). In Romania, the bark traps have been recommended in most papers published before 1960 (Olenici, and Olenici, 1994). After 1960, most cases recommend using toxic bark traps, treated with basic pesticides such as DDT or HCH (Olenici and Olenici, 1994). In the years before 1960, the product used to treat the traps was based on arsen (Hylarsol) (Olenici and Olenici, 1994). Before the widespread availability of pesticides, mass captures were done using sawdust piles (Leather et al., 1999); this method being used only if there was no felling nearby (Leather et al., 1999).

Other methods used to prevent and decrease damage by pine weevils include protective collars (Lindström et al., 1986) and shelters (von Sydow and Örlander, 1994). A mechanical method, Conniflex, based on protecting the seedlings physically against the gnawing of $\mathrm{H}$. abietis, has been described and evaluated in the field in forest plantations in Sweden. Conniflex is based on covering the stem with a layer of particles that do not allow the weevil to feed on the bark (Nordlander et al., 2008). This method appears to be more costly and requires substantial labor and time, considering the vast number of seedlings used in a forest plantation.

Additionally, various experiments have been carried out in Sweden to protect seedlings against $H$. abietis with the use of antifeedants (Nordlander, 1989). There have been attempts in finding antifeedants in non-host plants for the protection of Scots pine and Norway spruce seedlings. Tests pointed out that nonanoic acid has strong antifeedant properties against the pine weevil (Månsson, 2005). Furthermore, it has been shown that the feces of pine weevils contains some compounds with antifeedant effects (BorgKarlson et al., 2006). Anzeem et al. (2013) has later shown that the antifeedant compounds originates from microbes present in the frass and feces of ovipositing females, and could be used as an ecological alternative to insecticides.

In the following years, the idea of using entomopathogenic nematodes has been considered (Collins, 1993), as well as parasitic wasps (Henry, 1995) and other natural predators as control methods. Entomopathogenic nematodes (EPNs) of the families Steinernematidae and Heterorhabditidae (Nematoda: Rhabditida) have been shown to be lethal to insects, targeting the developmental stages of the pine weevil with the aim of suppressing the population (Dillon et al., 2006). Steinernema carpocapsae has been applied successfully to pine weevils at different stages of development, located in Sitka spruce stumps (Brixey et al., 2006), with this species being more effective at killing adults of $H$. abietis than $H$. downesi (Girling et al. 2010). 
Two blue stain fungi of the genus Ophiostoma and a yeast, Debaryomycetes hansenii, have been isolated from pine weevil frass, and been shown to produce Methyl salicylate (MeSA). MeSA is a compound that has proven to be a repellent or attractant between organisms; in the pine weevil's case having an inhibitory feeding effect (Anzeem et al., 2015). Beauveria caledonica, aentomopathogenic fungi isolated from $H$. abietis habitat, seems promising in suppressing the weevil population together with Metharizium brunneum and Beauveria bassiana. M. brunneum can persist in the felling site for at least two years, but more studies are necessary to determine their efficiency (McNamara et. al., 2018).

Silvicultural practices have also been adapted to control or reduce damage by the pine weevil. According to Scott and King (1974) the population of $H$. abietis could be reduced by removing the stumps from clear cuts, which in turn could be used as source of bioenergy. Theoretically, stump removal can reduce pine weevil damage (Rahman et al., 2016), however it is very costly. In Romania, debarking of stumps is practiced instead, being a measure that requires less time and effort and is therefore more affordable. In a similar way, it was recommended to use wood pole traps to attract weevils. Controlling the poles periodically, the weevils are collected and destroyed and the poles infested with eggs and larvae are burned, thus destroying the developing generation (Olenici and Olenici, 1994).

Wallertz et al. (2016) support the idea of an early planting (in autumn). Planting earlier allows the plants to grow and become more tolerant to pine weevil damage. Also, the plants manage to accumulate more biomass than the ones planted in winter/spring the following year. In a similar way, Nordlander et al. (2017) has shown that planting after the pine weevil emigration from clear-cuts is a better option compared to the current planting time. In addition to planting period, Hansen et al. (2017) hypothesized that harvesting of forest residues and the residue removal rate could have effects on the growth of Norway spruce seedling, and subsequently pine weevil damage. The results showed that where residues were removed, the seedlings had a better growth and the pine weevil damage was reduced (Handsen et al., 2017).

Mounding is an alternative used in Finland for Norway spruce seedlings. This practice promotes the growth of the seedlings after planting, resulting in more vigorous plants capable of recovering from pine weevil damage (Örlander and Nilsson, 1999). Luoranen et al. (2017) investigated whether mounding is efficient in preventing or reducing pine weevil damage in Norway spruce, for seedlings planted without insecticide treatments. Results have shown that the method has potential in mounds covered with pure mineral soil, if the seedlings stem has over $4 \mathrm{~mm}$ diameter. Another ecological mean of protection for seedlings could be the use of over-stories. It has been shown that over-stories of Norway spruce will decrease herbivory from the pine weevil in under-planted seedlings (Lof et al., 2004).

Lately, a large number of studies have focused on inducing the resistance of plants using the plant hormone methyl jasmonate (MeJa) (produced by plants various developmental processes and when stressed). Scots pine (Pinus sylvestris L., Pinaceae) produces a terpenoid resin which consists of monoterpenes and resin acids that offer protection against herbivores and pathogen attacks (Heijari et al., 2005). The changes in plant growth and chemical parameters after the MJ treatments indicate shifts in carbon allocation towards defense, but MJ also affects plant physiology and xylem development. Terpenoid resin production is tissue-specific, but generally increased after MJ treatments, which means that this compound may offer potential protection of conifers against herbivores (Heijari et al., 2005).

Other novel methods of plant protection could be explored. For instance, breeding trees for increased resistance against the pine weevil. Genetic variation for the levels of pine weevil damage received by plants has been found for Norway spruce and families with greater resistance have been identified (Zas et al., 2017). Thus, there is future potential for developing resistance breeding program in Norway spruce. Additionally, a clonal propagation method (somatic embryogenesis, SE) has been recently shown to confer greater resistance against pine weevils in Norway spruce (Puentes et al., 2018). Plants produced via SE or families with greater resistance could be used for re-planting in sites with high pine weevil pressure. Moreover, direct methods of controlling pine weevils are also being explored. For example, studies on other Curculionidae species have shown that sterilization of male adults is possible without 
damaging their mating ability, thus it should be taken in consideration for $H$. abietis as future control method (Sales et al., 2018).

\section{Conclusions}

Our understanding of the biology of the pine weevil, Hylobius abietis L., is vast, covering information from the morphology, life cycle, behavior, damage and means of control. Despite the depth of our knowledge on this insect, the pine weevil continues to be a pest causing immense damage and loss of plant material in European forests. Given the challenges we face with global changes in many climatic variable, much of the current knowledge should be evaluated under these future scenarios. Changes in the pine weevil's development might be drastic and entail adapting forest management practices and control measures. In particular, questions with regards to the emergence and sexual maturity of the insect should be addressed, as they could offer a clear and specific window to suppress the population. This should be accompanied by improvement of the plant material. Novel ideas of increasing the plant resistance as well as introducing plant material with repellent properties should be further considered.

Aknowledgements. This research did not receive any specific grant from funding agencies in the public, commercial, or not-for-profit sectors.

\section{References}

1. Albrecht EM, Davis EE, Venette RC. (2008). Exotic pine pests: survey reference. https://www.fs.usda.gov/ Internet/FSE_DOCUMENTS /fsbdev2_026444.pdf. Accessed 18.09.2018

2. Azeem M, Rajarao GK, Nordenhem H, Borg-Karlsson AK. (2013). Penicillium expansum Volatiles Reduce Pine Weevil Attraction to Host Plants 39: 120.

3. Azeem M, Kuttuva G R, Terenius O, Nordlander G, Nordenhem H, Nagahama K, Norin E, Borg-Karlson AK. (2015). A fungal metabolite masks the host plant odor for the pine weevil (Hylobius abietis). Fungal Ecology.13:103-111.

4. Brixey JM, Moore R, Milner AD. (2006). Effect of entomopathogenic nematode (Steinernema carpocapsae Weiser) application technique on the efficacy and distribution of infection of the large pine weevil (Hylobius abietis L.) in stumps of Sitka spruce (Picea sitchensis Carr.) created at different times. Forest Ecology Management 226:161-172.

5. Borg-Karlson AK, Nordlander G, Mudalige A, Nordenhem C, Unelius CR. (2006). Antifeedants in the Feces of the
Pine Weevil Hylobius abietis: Identification and Biological Activity 32: 943.

6. CABI. 2015. CABI Invasive Species Compendium. CAB International. Available on-line at: https://www.cabi.org/ isc/datasheet/28175, Accesed 14.09.2018.

7. Christiansen E, Bakke A. (1968). Temperature preference in dults of Hylobius abietis L. (Coleoptera, Curculionidae) during feeding and oviposition. Zeitschrift für Angewandte Entomologie. 62:83-89.

8. Davis EE, Albrecht EM, Venette RC. (2008). CPHST Pest Datasheet for Hylobius abietis. USDA-APHIS-PPQ-CPHST. http://download.ceris.purdue.edu/file/3158 Accessed 14.09.2018

9. Day KR, Nordlander G, Kenis M, Halldorson G. (2004). Biology and life cycles of bark weevils, pp. 331-349.

10. Dyderski MK, Paź S, Frelich LE, Jagodziński AM. (2017). How much does climate change threaten European forest tree species distributions?. Glob Change Biol.24:11501163.

11. Dillon AB, Ward D, Downes MJ, Griffin CT. (2006). Suppression of the large pine weevil Hylobius abietis (L.) (Coleoptera: Curculionidae) in pine stumps by entomopathogenic nematodes with different foraging strategies. Biological Control 38:217-226.

12. Fedderwitz F, Björklund N, Ninkovic V, Nordlander G. (2018). Does the pine weevil (Hylobius abietis) prefer conifer seedlings over other main food sources? Silva Fennica. 52:3:9946:9.

13. Girling RD, Ennis D, Dillon AB, Griffin CT. (2010). The lethal and sub-lethal consequences of entomopathogenic nematode infestation and exposure for adult pine weevils, Hylobius abietis (Coleoptera: Curculionidae). Journal of Invertebrate Pathology 104:3:195-202. ISSN 0022-2011.

14. Henry CJ. (1995). The effect of a braconid ectoparasitoid, Braconhylobii Ratz., on larval populations of the large pine weevil, Hylobius abietis L. PhD thesis, University of Ulster, Coleraine.

15. Heijari J, Nerg AM, Kainulainen P,Viiri H, Vuorinen M, Holopainen J.K. (2005). Application of methyl jasmonate reduces growth but increases chemical defence and resistance against Hylobius abietis in Scots pine seedlings. Entomologia Experimentalis et Applicata. 115: 117-124.

16. Inward DJ, Wainhouse D, Peace A. (2012). The effect of temperature on the development and life cycle regulation of the pine weevil Hylobius abietis and the potential impacts of climate change. Agricultural and Forest Entomology, 14: 348-357.

17. Kindvall O, Nordlander G, Nordenhem H. (2000). Movement behaviour of the pine weevil Hylobius abietis in relation to soil type: an arena experiment. Entomol Exp Appl 95:53-61

18. Långström B, Day K. (2007). Damage, Control and Management of Weevil Pests, Especially Hylobius abietis. In: Lieutier F., Day K.R., Battisti A., Grégoire JC., Evans H.F. (eds) Bark and Wood Boring Insects in Living Trees in Europe, a Synthesis. Springer.Dordrecht

19. Leather SR, Day KR, Salisbury A. (1999). The biology and ecology of the large pine weevil, Hylobius abietis 
(Coleoptera: Curculionidae): A problem of dispersal?. Bulletin of Entomological Research. 89. 3 - 16.

20. Lekander B, Eidmann HH, Bejer B, Kangas E. (1985). Time of oviposition and its influence on the development ofHylobius abietis (L.) (Col., Curculionidae).Z. Angew. Entomol. 100:417-421.

21. Lindström A, Hellqvist C, Gyldberg B, Långström B, Mattsson A. (1986). Field performance of a protective collar against damage by Hylobius abietis. Scandinavian Journal of Forest Research1, 3-15

22. Luoranen J, Viiri H. (2005). Insecticides sprayed on seedlings of Picea abies during active growth: Damage to plants and effect on pine weevils in bioassay, Scandinavian Journal of Forest Research, 20:1, 47-53.

23. Lundborg L, Sampedro L, Borg-Karlson AK, Zas R. (2018). Effects of methyl jasmonate on the concentration of volatile terpenes in tissues of Maritime pine and Monterey pine and its relation to pine weevil feeding (2018).

24. Månsson PE, Schlyter F. (2004). Hylobius pine weevils adult host selection and antifeedants: feeding behaviour on host and non host woody scandinavian plants. Agricultural and Forest Entomology, 6: 165-171.

25. Månsson PE. (2005). Host selection and antifeedants in Hylobius abietis pine weevils. Diss. (sammanfattning/ summary) Alnarp : Sveriges lantbruksuniv., Acta Universitatis agriculturae Sueciae, 1652-6880 ; 2005:16 ISBN 91-576-7015-3 [Doctoral thesis]

26. McNamara L, Christine T, Griffin CT, Fitzpatrick D, Kavanagh K, Carolan JC. (2018). The effect of entomopathogenic fungal culture filtrate on the immune response and haemolymph proteome of the large pine weevil, Hylobius abietis.

27. Nordlander G. (1987). Amethod for trapping Hylobius abietis (L.)with a standardized bait and its potential for forecastingseedling damage. Scandinavian Journal of Forest Research 2

28. Nordlander G, Nordenhem H, Hellqvist C. (2008). A flexibile sand coating (Connifleex) for the proection of conifer seedlings against damage by the pine weevil Hylobius abietis

29. Nordlander G, Hellqvist C, Hjelm K. (2017). Replanting conifer seedlings after pine weevil emigration in spring decreases feeding damage and seedling mortality. Scandinavian Journal of Forest Research.32:1, 60-67.

30. Olenici N, Olenici V. (1994). Hylobius abietis L. particularități biologice, ecologice, comportamentale și protecția culturilor împotriva vătămărilor cauzate de acesta. Bucovina Forestieră

31. Olenici N, Olenici V., (2006). Antifeedant effect of NeemAzal-T/S on the large pine weevil Hylobius abietis L. 49.

32. Örlander G, Nilsson U. (1999). Effect of Reforestation Methods on Pine Weevil (Hylobius abietis) Damage and Seedling Survival, Scandinavian Journal of Forest Research, 14:4, 341-354.

33. Petersson M, Nordlander G, Örlander G. (2006). Why vegetation increases pine weevil damage: Bridge or
shelter?,Forest Ecology and Management, 225:1-3:368377.

34. Pitkänen A, Törmänen $K$, Kouki J, Järvinen E,Viiri $H$. (2005). Effects of green tree retention, prescribed burning and soil treatment on pine weevil (Hylobius abietis and Hylobius pinastri) damage to planted Scots pine seedlings. Agricultural and Forest Entomology, 7: 319-331.

35. Pitkänen A, Kouki J, Viiri H, Martikainen P. (2008). Effects of controlled forest burning and intensity of timber harvesting on the occurrence of pine weevils, Hylobius spp., in regeneration areas. Forest Ecology and Management. 255:3-4:522-529.

36. Puentes A, Högberg K-A, Björklund N, Nordlander G (2018). Novel Avenues for Plant Protection: Plant Propagation by Somatic Embryogenesis Enhances Resistance to Insect Feeding. Front. Plant Sci. 9:1553.

37. Rahman A, Viiri H, Tikkanen OP. (2018). Is stump removal for bioenergy production effective in reducing pine weevil (Hylobius abietis) and Hylastes spp. breeding and feeding activities at regeneration sites?. Forest Ecology and Management. 424:184-190.

38. Rose D, Leather SR, Matthews GA. (2005). Recognition and avoidance of insecticide treated Scots Pine (Pinus sylvestris) by Hylobius abietis (Coleoptera: Curculionidae): implications for pest management strategies. Agricultural and Forest Entomology, 7: 187-191.

39. Sales K, Vasudeva R, Dickinson ME, Godwin JL, Lumley AJ, Michalczyk L, Hebberecht L, Thomas P, Franco A, Gage MJG. (2018). Experimental heatwaves compromise sperm function and cause transgenerational damage in a model insect. Nature Communications 9:4771.

40. Scott TM, King CJ.(1974). The large pine weevil and blackpine beetles. Forestry Commission Leaflet 58, London, HMSO.

41. Tan JY, Wainhouse D, Day KR, Morgan G. (2010). Flight ability and reproductive development in newly emerged pine weevil Hylobius abietis and the potential effects of climate change. Agricultural and Forest Entomology, 12: 427-434.

42. Thorpe K, Day K. (2008). Reproductive maturation in the large pine weevil Hylobius abietis: the relative importance of larval and adult diet. Agricultural and Forest Entomology, 10: 53-59.

43. Tilles DA, Nordlander G, Nordenhem H, Eidmann HH, Wassgren A, Bergström G. (1986). Increased release of host volatiles from feeding scars: A major cause of field aggregation in the pine weevil Hylobius abietis (Coleoptera: Curculionidae).Environmental Entomology. 15:1050-1054.

44. Tilles DA, Eidmann HH, Solbreck B. (1988). Mating stimulant of the pine weevil Hylobius abietis (L.) 14: 1495.

45. Viiri H, Tuomainen A, Tervo L. (2007). Persistence of deltamethrin against Hylobius abietis on Norway spruce seedlings. Scandinavian Journal of Forest Research. 22:2, $128-135$.

46. Voolma K. (1994). Use of baited traps in monitoring Hylobius abietis and associated Hylastes-species. Forest Reseach Institute. Estonian Agricultural University. 
47. von Sydow F, Örlander G.(1994). The influence of shelterwood density on Hylobius abietis occurrence and feeding onplanted conifers. Scandinavian Journal of Forest Research9, 367-375.

48. Wallertz K. (2005). Pine weevil Hylobius abietis feeding in shelterwood systems. ISBN: 9157668752.

49. Wallertz K, Nordenhem H, Nordlander G. (2014). Damage by the pine weevil Hylobius abietis to seedlings of two native and five introduced tree species in Sweden. Silva Fennica 48:4.1188.14.

50. Wallertz K, Hanssen KH, Hjelm K, Fløistad IS. (2016) Effects of planting time on pine weevil (Hylobius abietis) damage to Norway spruce seedlings, Scandinavian Journal of Forest Research.

51. Wu S, Kostromytska OS, Xue F, Koppenhöfer AM. (2018). Chilling effect on termination of reproductive diapause in Listronotus maculicollis (Coleoptera: Curculionidae). Journal of Insect Physiology.104:25-32.

52. Zas R, Björklund N, Sampedro L, Hellqvist C, Karrlson B, Jonsson S, Nordlander G. (2017). Genetic variation in resistance of Norway spruce seedlings to damage by the pine weevil Hylobius abietis. Tree Genetics \& Genomes 13: 111. 